\title{
Bone-Anchored Hearing Implants: Surgical and Audiological Comparison of Different Surgical Techniques
}

\author{
Merve Torun Topcu ${ }^{1 \odot}$ \\ Basak Mutlu10 Serdal Celik ${ }^{2}$ (1) \\ Bahtiyar Celikgun ${ }^{3}$ \\ Ahmet Mutlu ${ }^{2}$ \\ M. Tayyar Kalcioglu2
}

${ }^{1}$ Department of Audiology, Istanbul Medeniyet University, School of
Health Sciences, Istanbul, Turkey
2 Department of Otorhinolaryngology, Istanbul Medeniyet University
School of Medicine, Goztepe Training and Research Hospital,
Istanbul, Turkey
${ }^{3}$ Marmara University, Health Sciences Institutes, Audiology Program,
Istanbul, Turkey

Address for correspondence Serdal Celik, MD, Department of Otorhinolaryngology, Istanbul Medeniyet University, Goztepe Training and Research Hospital, Istanbul, Turkey (e-mail: serdal.celik77@hotmail.com).

Int Arch Otorhinolaryngol 2022;26(4):e649-e656.

\begin{abstract}
Introduction The bone-anchored hearing implant system (BAHS) is an effective amplification system that transmits the sounds received by an external operating system to the inner ear by bypassing the middle ear placed in the temporal bone.

Objective This study compares the results of patients who underwent bone-anchored hearing implant system (BAHS) surgery using two different surgical methods in terms of preoperative and postoperative complications, surgical time, audiological findings, and patient satisfaction.

Methods The results of 22 patients who underwent BAHS were evaluated retrospectively from video records and audiological results, The Turkish Version of the Glasgow Benefit Inventory (GBI) questionnaire were evaluated. Two different surgical approaches were used for implantation: the linear incision technique $(n=9)$ and the punch technique $(n=13)$.

\section{Keywords}

- bone-anchored implants

- quality of life

- hearing tests

- punch technique

- linear incision technique

Results Mean surgical durations were $9.67 \pm 2.85$ and $47.65 \pm 6.13$ minutes for Groups A and B, respectively, and these were significantly different $(p<0.001)$. There were no significant differences between the groups' speech recognition scores for a signal-to-noise ratio (SNR) of $+5(p=0.173)$, SNR of $0(p=0.315)$, or SNR of -5 $(p=0.360)$ and results of the GBI scores.

Conclusion The punch technique has a significant advantage due to a shorter surgery duration without increased surgical complications. Additionally, the punch technique showed no significant difference in hearing performance or satisfaction compared with linear incision.
\end{abstract}

received

May 27, 2021

accepted after revision

December 2, 2021

published online

March 2, 2022
DOI https://doi.org/

10.1055/s-0042-1742765. ISSN 1809-9777. (c) 2022. Fundação Otorrinolaringologia. All rights reserved.

This is an open access article published by Thieme under the terms of the Creative Commons Attribution-NonDerivative-NonCommercial-License, permitting copying and reproduction so long as the original work is given appropriate credit. Contents may not be used for commercial purposes, or adapted, remixed, transformed or built upon. (https://creativecommons.org/ licenses/by-nc-nd/4.0/)

Thieme Revinter Publicações Ltda., Rua do Matoso 170, Rio de Janeiro, RJ, CEP 20270-135, Brazil 


\section{Introduction}

One of the major goals for people who have conductive hearing loss (CHL), mixed hearing loss, or single-sided deafness is to restore their hearing as far as possible. In particular cases, which are reconstructed with surgical techniques, amplification systems are utilized according to the characteristics of the hearing loss. The bone-anchored hearing implant system (BAHS) is an effective amplification system that transmits the sounds received by an external operating system to the inner ear by bypassing the middle ear via a titanium implant placed in the temporal bone. This system was first implemented in 1977 by Tjellström. ${ }^{1}$ The BAHS is used to improve hearing and increase patients' quality of life, and it has shown good results in patients with mixed hearing loss, CHL, or single-sided deafness. ${ }^{2,3}$ Tjellström first described this surgical technique in two stages-the initial stage was the placement of titanium implants in the temporal bone, while the second stage was the placement of the external part of the implant (abutment) using a skin incision a few months later. ${ }^{1}$ These two stages have since been combined into one procedure. ${ }^{4}$ To minimize postoperative soft tissue problems, new surgical methods such as the U-flap technique, the dermatome technique, and the linear incision technique with the removal of subcutaneous tissue have been used. ${ }^{5,6}$ In recent years, BAHS surgery without tissue reduction has become popular. Hultcrantz was the first to publish the clinical outcomes of this technique, and the use of tissue protection techniques has since gained popularity. ${ }^{7}$

Another method that has gained popularity in recent years is the punch technique, which is performed without skin incision. Goldman et al. indicated that the punch technique is successful in terms of surgery duration and tissue reaction. ${ }^{8}$ Although there have been some studies in the literature regarding the punch technique, few studies present a comparison between the punch technique and the linear incision technique without subcutaneous tissue removal. ${ }^{9,10}$ This study aims to present the surgical and audiological outcomes of BAHS surgery performed by the same surgeon using either the punch technique or subcutaneous tissue-preserving linear incision technique.

\section{Methods}

\section{Methods}

A total of 22 patients who underwent BAHS surgery (PONTO; Oticon Medical AB, Askim, Sweden) between January 2012 and November 2019 were evaluated in this retro-prospective study after receiving approval from the local ethics committee (Istanbul Medeniyet University Clinical Studies Ethic Committee, 27 June 2018, 2018/0259). Although BAHS is indicated in the case of single-sided deafness, patients with conductive or mixed hearing loss were evaluated in this study. Implant application was performed in the ear with a bone conduction threshold of $60 \mathrm{~dB}$ and more, and a speech discrimination score of greater than $60 \%$. The patients were divided into two groups: 13 patients who were given implants using the punch technique (Group A) and 9 patients who underwent the subcutaneous tissue-preserving linear incision technique (Group B). As the control group, 20 normal-hearing young adults were also included in the study. Demographic characteristics, BAHS indications, surgical methods, perioperative and postoperative complications, and preoperative and postoperative audiological results were evaluated. Surgical video recordings were evaluated, and operation times were recorded. Patients were included in the study after at least 1 year from the date of the surgical operation. The patient from the linear incision technique group and from the punch technique group had their first follow up examination around 15 days after the surgery and the second follow up examination between 1 to 2 months after surgery. The mean follow-up time was 114 months for the linear incision technique group and 53 months for the punch technique group. Preoperative and postoperative complications were evaluated using the Holger classification. (Grade 0: Normal skin; Grade 1: Reddish; Grade 2: Red and moist; Grade 3: Tissue granulation; Grade 4: Skin complication leading to removal of the abutment and/or skin overgrowth). ${ }^{11}$

\section{Surgical Techniques}

Before surgery, all surgical procedures were explained to the patients in detail. None of the patients preferred local anesthesia. According to patient's preferences, all of the surgeries were performed under general anesthesia with standard surgical cleaning and covering. The location was marked $6 \mathrm{~cm}$ posterior superior from the tragus on an axis with a $45^{\circ}$ angle of the horizontal line. The thickness of skin and subcutaneous tissue was measured with a needle and methylene blue was used to mark the projection of this point at the skull.

\section{Punch Technique}

A $0.5 \mathrm{~mm}$ size punch from a $12 \mathrm{~mm}$ implant system was used to create a circular cut through the full thickness of the scalp. After removal of tissue, the periosteum was elevated to expose the cortical bone. The implant system drill was used at $2,000 \mathrm{rpm}$ to initially prepare the $3.5 \mathrm{~mm}$ implant bed on the cortical bone and, if the thickness of the bone was appropriate, the bed width was extended to $4 \mathrm{~mm}$. Depending on the skin thickness, either a 9-mm or a $12-\mathrm{mm}$ titanium implant was placed in the hole (-Fig. 1).

\section{Subcutaneous Tissue-Preserving Linear Incision Technique}

A $4-5-\mathrm{cm}$ vertical line incision was made $1 \mathrm{~cm}$ on the anterior of the marked region. The periosteum was reached after passing through the skin and the subcutaneous tissue. The area that had been stained with methylene blue was located, and the cortical bone was exposed after the elevation of the periosteum. The implant system drill was used at $2000 \mathrm{rpm}$ to prepare the $3.5-\mathrm{mm}$ implant bed on the cortical bone, and, providing that the thickness of the bone was appropriate, the hole was extended to $4.0 \mathrm{~mm}$. Depending on the skin thickness, either a $9-\mathrm{mm}$ or $12-\mathrm{mm}$ titanium 


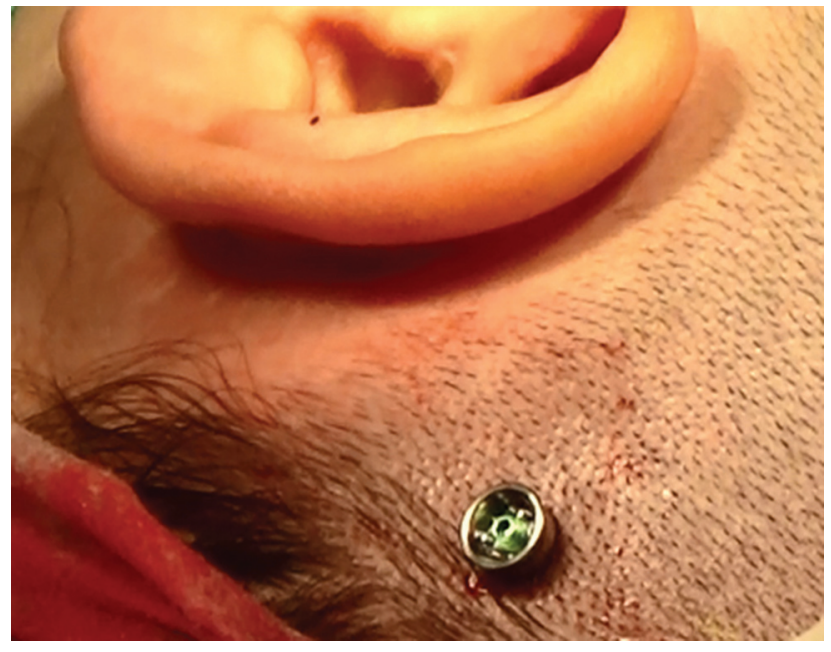

Fig. 1 Implant placement using puncture technique.

implant was placed in the bed. A punch was used to remove the skin and subcutaneous tissue in the previously marked area, and then the head of the titanium implant was placed over this hole (-Fig. 2). Subcutaneous tissue and skin were closed with absorbable and non-absorbable sutures.

\section{Audiological Evaluation}

Although there are two different surgical methods, it can be predicted that audiologically, different results will not be obtained as the working principle of both implants is the same. However, in this study, it was determined that it would be beneficial to show whether there is a difference between the audiological results when comparing the advantages and disadvantages of the two different methods. Nineteen patients with bilateral hearing loss who underwent unilateral BAHS surgery were evaluated audiologically. Audiological evaluation could not be assessed for the remaining three patients (one of whom had single-sided deafness) as they had received the implant a few days before this analysis and had not yet begun to use the hearing implant. The air and bone conduction thresholds were measured using a pure tone audiometry test $(250-8,000 \mathrm{~Hz}$ for air conduction and $500-$ $4,000 \mathrm{~Hz}$ for bone conduction), and a speech audiometry test

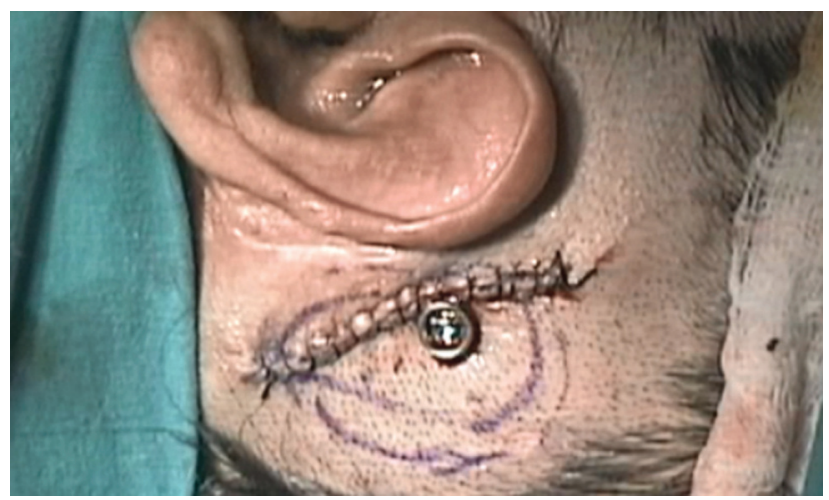

Fig. 2 Implant placement using subcutaneous tissue-preserving linear incision technique. was performed using the Astera 2 clinical audiometer (MadsenOtometrics, Denmark) pre and postoperatively. TDH 39 supraaural headphones (Telephonics, Farmingdala, NY, USA) were used to determine air conduction thresholds. Bone conduction thresholds were determined using a RadioEar B71 bone vibrator. Postoperative three-month hearing thresholds $(250-8,000 \mathrm{~Hz})$ with BAHS were determined in free field using a loudspeaker. The loudspeaker was located at $0^{\circ}$ azimuth and $1 \mathrm{~m}$ from the patient and warble tones were presented.

The speech reception threshold and word recognition tests were assessed preoperatively using TDH39 headphones in quiet conditions. To assess postoperative word-recognition performance with BAHS in noise, a speech-in-noise test was performed using the Turkish monosyllabic word recognition list in free field. ${ }^{12}$ Three signal-to-noise ratios (SNRs; + 5, 0, -5) were used to determine the speech-in-noise scores. The speech-in-noise test was conducted using two speakers in free field. The white noise speaker was located behind the listener ( $180^{\circ}$ azimuth), and the speech stimulus speaker was located in front of the listener ( $0^{\circ}$ azimuth). Single-syllable word recognition scores with BAHS were determined in quiet and $+5,0$, and -5 SNRs. The same word list was administered to all participants. The list has consonant-vowel-consonant formatted 25 monosyllabic phonemically balanced words. The correct answers were graded as "4" points, and the incorrect answers were graded as " 0 " points. The words were presented at a sensation level of $40 \mathrm{~dB}$. Word recognition scores were calculated based on the correct number of repeated words by each SNR in free field. The data of 20 healthy participants were included in the study as a control. Air conduction hearing thresholds were $0-25 \mathrm{~dB}$ hearing level $(250-8,000 \mathrm{~Hz})$. Pure tone audiometry and word-recognition test results $(+5,0$, and $-5 \mathrm{~dB}$ SNRs and quiet) were evaluated. All audiological tests were performed in a double-walled, sound-isolated audiometric booth.

The Turkish Version of the Glasgow Benefit Inventory (GBI) questionnaire was used to evaluate patient satisfaction. ${ }^{13}$ The questionnaire, which can be completed by interview or self-completed by patients, consists of 18 questions answered using a 5-point Likert scale, addressing change in health status post any intervention. Principal component analysis found that questions from the GBI were subdivided and loaded reliably onto three distinct subscales. Twelve questions focused on general changes in health status, as well as changes in psychosocial health status were termed 'general score'. A further three questions were related to the amount of social support needed in relation to the condition being questioned (social score). The remaining three questions addressed changes in physical health status including medications requirement and number of visitations to doctors required (physical score).

\section{Statistical Analyses}

All data were collected and analyzed using IBM SPSS Statistics for Windows, Version 23.0 (IBM Corp., Armonk, NY, USA). All analyses were conducted using a confidence interval of $95 \%$, and $p<0.05$ was accepted as the limit for statistical significance. The nominal and ordinal data were analyzed using Pearson 
652 Bone-Anchored Hearing Implants Topcu et al.

chi-squared and Fisher exact tests, and the scale data were analyzed using the Mann-Whitney U test.

\section{Results}

The demographic data and surgical indications of the groups are given in - Table 1 .

\section{Duration of the Surgery}

In group A (13 patients), the surgery durations ranged from 4.56 to 14.29 minutes (mean $=9.67 \pm 2.85$ minute). The surgery durations in group B ( 9 patients) ranged from 31.33 to 60.48 minutes (mean $=47.65 \pm 6.13$ minute) (-Table 1). There was a significant difference between the mean surgery durations for these two groups $(p<0.001)$.

\section{Complications}

In Group A, granulation tissue with skin necrosis (Holger classification grade 3 ) around the implant developed in one patient in the early postoperative period (15-Day) (-Fig. 3); however, a full recovery was observed after dressing and local treatment with corticosteroid and antibiotic pomades. It is believed that this necrosis occurred due to the prolonged mastoid pressure dressing, which was removed only after 20 days, as the patient did not attend the follow-up on day 10. In group $B$, granulation tissue (Holger classification grade 3 ) was seen around the implant in a child patient six months after the surgery. This occurred several days after the child had returned to school ( $\mathbf{- T a b l e} \mathbf{1}$ ). The problem was solved with topical corticosteroid treatment. There was no significant difference in the incidence of complications when groups $A$ and B were compared using Pearson chi-squared and Fisher exact tests $(p>0.05)$.

\section{Audiological Results}

There were no significant differences between the two groups regarding pre and postoperative air and bone conduction hearing thresholds (-Table 2). Postoperative free-field

Table 1 Demographic and surgical features of BAHS patients

\begin{tabular}{|c|c|c|c|c|c|c|c|c|c|c|}
\hline \multirow{2}{*}{$\begin{array}{l}\text { Patient } \\
\text { No } \\
1\end{array}$} & \multicolumn{2}{|c|}{ Age } & \multirow{2}{*}{$\begin{array}{l}\text { Gender } \\
\text { Male }\end{array}$} & \multirow{2}{*}{$\begin{array}{l}\text { Indication } \\
\mathrm{COM} \\
\end{array}$} & \multirow{2}{*}{$\begin{array}{l}\begin{array}{l}\text { Surgical } \\
\text { Technique }\end{array} \\
\text { Punch } \\
\end{array}$} & \multirow{2}{*}{$\begin{array}{l}\text { Type of } \\
\text { hearing } \\
\text { loss } \\
\text { Mixed }\end{array}$} & \multicolumn{2}{|c|}{$\begin{array}{l}\text { Duration of surgery } \\
\text { (minute) }\end{array}$} & \multirow{2}{*}{$\begin{array}{l}\text { Postoperative } \\
\text { Complications } \\
\text { No }\end{array}$} & \multirow{2}{*}{$\begin{array}{l}\text { Side } \\
\text { Right } \\
\end{array}$} \\
\hline & 22 & $32.3 \pm 16.7$ & & & & & 8.00 & $9.67 \pm 2.85$ & & \\
\hline 2 & 20 & & Male & COM & Punch & Mixed & 6.55 & & No & Left \\
\hline 3 & 54 & & Male & COM & Punch & Mixed & 8.32 & & No & Left \\
\hline 4 & 58 & & Male & COM & Punch & Mixed & 9.27 & & No & Right \\
\hline 5 & 40 & & Male & $\mathrm{COM}$ & Punch & Mixed & 4.56 & & No & Left \\
\hline 6 & 52 & & Male & COM & Punch & Mixed & 14.29 & & No & Left \\
\hline 7 & 7 & & Female & COM & Punch & Mixed & 12.56 & & $\begin{array}{l}\text { Holger } \\
\text { Classification } \\
\text { Grade } 3\end{array}$ & Left \\
\hline 8 & 14 & & Male & EACA & Punch & $\mathrm{CHL}$ & 9.52 & & No & Right \\
\hline 9 & 47 & & Male & COM & Punch & Mixed & 11.28 & & No & Left \\
\hline 10 & 10 & & Male & EACA & Punch & $\mathrm{CHL}$ & 9.57 & & No & Left \\
\hline 11 & 6 & & Male & SSD & Punch & SNHL & 9.04 & & No & Left \\
\hline 12 & 47 & & Female & $\mathrm{COM}$ & Punch & Mixed & 11.57 & & No & Left \\
\hline 13 & 43 & & Female & COM & Punch & Mixed & 11.27 & & No & Right \\
\hline 14 & 35 & $29.12 \pm 15.8$ & Male & COM & LIT & Mixed & 46.02 & $46.35 \pm 6.13$ & No & Left \\
\hline 15 & 21 & & Male & COM & LIT & Mixed & 50.45 & & No & Right \\
\hline 16 & 52 & & Male & COM & LIT & Mixed & 31.33 & & No & Left \\
\hline 17 & 15 & & Male & EACA & LIT & $\mathrm{CHL}$ & 45.20 & & No & Right \\
\hline 18 & 18 & & Female & COM & LIT & Mixed & 60.48 & & No & Left \\
\hline 19 & 39 & & Male & $\mathrm{COM}$ & LIT & Mixed & 44.02 & & No & Right \\
\hline 20 & 5 & & Male & COM & LIT & Mixed & 57.02 & & $\begin{array}{l}\text { Holger } \\
\text { Classification } \\
\text { Grade } 3\end{array}$ & Left \\
\hline 21 & 29 & & Female & EACA & LIT & $\mathrm{CHL}$ & 45.12 & & No & Left \\
\hline 22 & 30 & & Female & COM & LIT & Mixed & 49.18 & & No & Right \\
\hline
\end{tabular}

Abbreviations: CHL, Conductive Hearing Loss; COM, Chronic otitis media; EACA, External auditory canal atresia; LIT, Linear incision technique; SNHL, Sensorineural Hearing Loss; SSD, single sided deafness. 


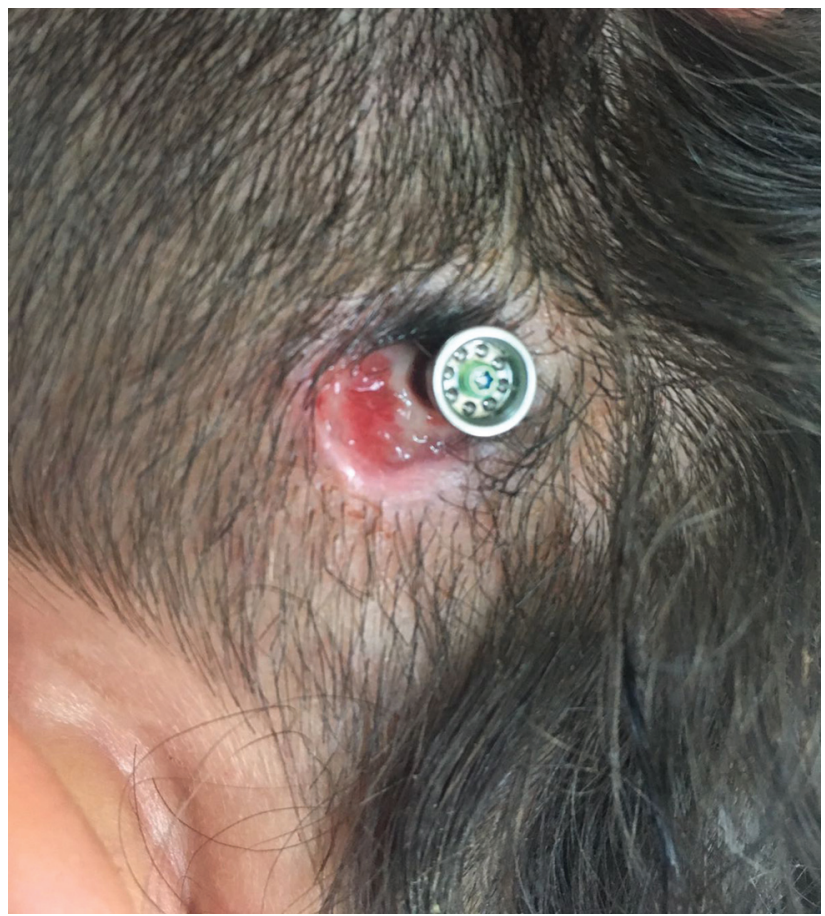

Fig. 3 Skin necrosis around the implant.

hearing thresholds with BAHS were significantly better than preoperative hearing for both groups ( $p<0.001$; - Table 3 ).

There were no significant differences in postoperative word recognition scores with supra-aural headphones between groups A and B. However, there was a statistically significant improvement in word recognition scores with BAHS in free field $(p<0.001$; - Table 4$)$. The best word recognition scores were obtained in the $+5 \mathrm{~dB}$ SNR in both groups for the speech-in-noise test. The scores declined with each decrease in SNR ( +5 to 0 and again to $-5 \mathrm{~dB}$ SNR). When the scores of group A and group B were compared, similar results were obtained $(p>0.05)$ ( $~$ Table 4$)$. When comparing the speech-in-noise scores for both groups of patients with the normal hearing group, the control group showed better recognition scores ( - Table 4 ).

There were no significant differences between the two groups regarding patient satisfaction with BAHS as evaluated with the GBI questionnaire. There was high patient satisfaction in all subscales and total scores ( - Table 5 ).

\section{Discussion}

\section{Discussion of Surgical Results and Complications}

The BAHS has become a successful system for auditory rehabilitation in the case of recurrent problems such as chronic otitis media (where conventional hearing aids cannot be used), for congenital ear malformation, for external ear canal infections that cannot be treated, or for single-sided deafness. ${ }^{14}$

The BAHS surgical methods have improved over the years to become less invasive. ${ }^{15}$ These surgical approaches originated with the U-flap technique that was followed by the dermatome technique, the linear incision technique with subcutaneous tissue removal, the linear incision technique with subcutaneous

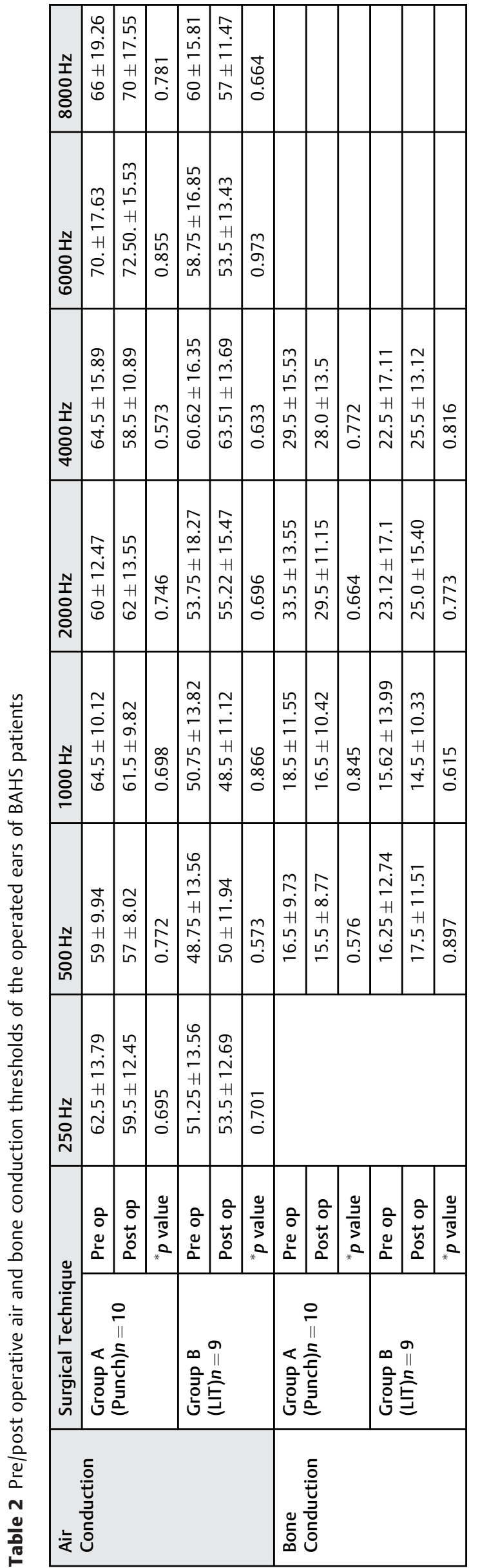

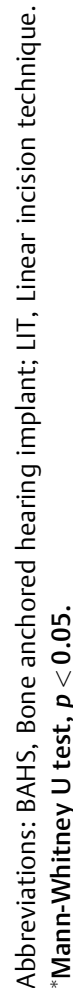


654 Bone-Anchored Hearing Implants Topcu et al.

Table 3 Postoperative free-field warble tone hearing thresholds with BAHS on

\begin{tabular}{|l|c|c|c|c|c|c|}
\hline $\begin{array}{l}\text { Surgical } \\
\text { Technique }\end{array}$ & $250 \mathrm{~Hz}$ & $500 \mathrm{~Hz}$ & $1000 \mathrm{~Hz}$ & $2000 \mathrm{~Hz}$ & $4000 \mathrm{~Hz}$ & $6000 \mathrm{~Hz}$ \\
\hline $\begin{array}{l}\text { Group A } \\
\text { (Punch) } n=10\end{array}$ & $34 \pm 8.43$ & $28 \pm 12.95$ & $14 \pm 11.01$ & $21.5 \pm 7.83$ & $35.5 \pm 14.99$ & $34.5 \pm 15.89$ \\
\hline $\begin{array}{l}\text { Group B } \\
\text { (LIT) } n=9\end{array}$ & $29.37 \pm 8.21$ & $20 \pm 5.97$ & $13.75 \pm 4.43$ & $25.62 \pm 11.16$ & $31.25 \pm 13.29$ & $34.37 \pm 13.74$ \\
\hline${ }^{*} p$ value & 0.274 & 0.203 & 0.829 & 0.46 & 0.573 & 0.829 \\
\hline
\end{tabular}

Abbreviation: LIT, Linear incision technique.

*Mann-Whitney U test, $\mathbf{p}<\mathbf{0 . 0 5}$.

Table 4 Pre and postoperative word recognition scores (WRS) (\%)

\begin{tabular}{|c|c|c|c|c|c|c|}
\hline $\begin{array}{l}\text { Surgical } \\
\text { Technique }\end{array}$ & $\begin{array}{l}\text { Pre-op word } \\
\text { recognition } \\
\text { scores }\end{array}$ & $\begin{array}{l}\text { Post-op word } \\
\text { recognition } \\
\text { scores }\end{array}$ & $\begin{array}{l}\text { Word recognition } \\
\text { scores in quite } \\
\text { with BAHS }\end{array}$ & $\begin{array}{l}\text { Word recognition } \\
\text { scores in }+5 \mathrm{~dB} \\
\text { SNR with BAHS }\end{array}$ & $\begin{array}{l}\text { Word recognition } \\
\text { scores in } 0 \mathrm{~dB} \\
\text { SNR with BAHS }\end{array}$ & $\begin{array}{l}\text { Word recognition } \\
\text { scores in }-5 \mathrm{~dB} \\
\text { SNR with BAHS }\end{array}$ \\
\hline $\begin{array}{l}\text { Group A } \\
\text { (Punch) } \\
n=10\end{array}$ & $84.4 \pm 8.09$ & $81.4 \pm 10.24$ & $88.4 \pm 8.09$ & $81.6 \pm 7.10$ & $67.2 \pm 10.46$ & $52.8 \pm 11.28$ \\
\hline $\begin{array}{l}\text { Group B (LIT) } \\
\mathrm{n}=9\end{array}$ & $86 \pm 10.69$ & $89 \pm 9.97$ & $91 \pm 9.01$ & $88.5 \pm 10.12$ & $78 \pm 14.96$ & $65.5 \pm 18.99$ \\
\hline $\begin{array}{l}{ }^{*} p \text { value } \\
\text { (GroupA and B) }\end{array}$ & 0.829 & 0.173 & 0.46 & 0.173 & 0.315 & 0.36 \\
\hline Control Group & & & $\begin{array}{l}\text { Word recognition } \\
\text { scores in quite }\end{array}$ & $\begin{array}{l}\text { Word recognition } \\
\text { scores in }+5 \mathrm{~dB} \text { SNR }\end{array}$ & $\begin{array}{l}\text { Word recognition } \\
\text { scores in } 0 \mathrm{~dB} \text { SNR }\end{array}$ & $\begin{array}{l}\text { Word recognition } \\
\text { scores in }-5 \mathrm{~dB} \text { SNR }\end{array}$ \\
\hline $\begin{array}{l}\text { Normal Hearing } \\
n=20\end{array}$ & - & - & $98.6 \pm 5.68$ & $95.2 \pm 5.72$ & $92.4 \pm 8.25$ & $84.8 \pm 7.86$ \\
\hline $\begin{array}{l}{ }^{*} p \text { value } \\
\text { (GroupA and } \\
\text { normal hearing) }\end{array}$ & - & - & $0.008^{*}$ & $0.005^{*}$ & $0.001^{*}$ & $0.001^{*}$ \\
\hline $\begin{array}{l}{ }^{*} p \text { value } \\
\text { (GroupB and } \\
\text { normal hearing) }\end{array}$ & - & - & $0.008^{*}$ & $0.005^{*}$ & $0.001^{*}$ & $0.001^{*}$ \\
\hline
\end{tabular}

Abbreviations: BAHS, Bone anchored hearing implant; LIT, Linear incision technique.

*Mann-Whitney U test, $\mathbf{p}<\mathbf{0 . 0 5}$.

Table 5 GBI questionnaire results for both groups

\begin{tabular}{|l|l|l|l|l|}
\hline Surgical Technique & Total Score & General Score & Social Score & Physical Score \\
\hline Group A Punch) $\boldsymbol{n}=\mathbf{1 0}$ & $54.50 \pm 5.56$ & $36.9 \pm 3.98$ & $9.9 \pm 1.19$ & $7.70 \pm 1.94$ \\
\hline Group B (LIT) $\boldsymbol{n}=\mathbf{9}$ & $55.66 \pm 5.19$ & $37.11 \pm 4.19$ & $10.22 \pm 0.83$ & $8.33 \pm 1.73$ \\
\hline${ }^{*} \boldsymbol{p}$ value & 0.661 & 0.968 & 0.497 & 0.447 \\
\hline
\end{tabular}

Abbreviations: GBI: The Turkish Version of the Glasgow Benefit Inventory; LIT, Linear incision technique.

Mann-Whitney U test, $\boldsymbol{p}<0.05$.

tissue preservation, and punching without incision. ${ }^{5-8}$ Although there are many studies on the preoperative and postoperative results of these techniques, as far as can be ascertained, this is the first study comparing the advantages and disadvantages of the newest and minimally invasive punch technique to the linear incision technique without subcutaneous tissue removal.

Caruso et al. reported the mean duration of surgery for the linear incision technique with preservation of subcutaneous tissue to be 20.3 minutes. ${ }^{15}$ Alshehri et al. reported a significant reduction in the duration of surgery using the modified punch technique. ${ }^{16}$ Goldman et al. reported a mean surgery duration of 15.2 minutes using the punch technique. ${ }^{8}$ In this study, the mean surgery duration for the linear incision technique was 47.65 minutes, whereas the duration of surgery for the punch technique was 9.67 minutes. The difference in surgery duration between the two groups was significant $(p<0.001)$. Although not comparative, similar results have been emphasized in several other studies. ${ }^{3,8,16}$ In the current study, the surgical duration of the punch technique was shorter than that reported by Goldman et al. ${ }^{8}$ However, the surgery duration using the incision technique was longer in this study than in that of Caruso et al. $^{15}$ This is possibly due to differences in the surgical approach between surgeons. ${ }^{15}$ In the current study, it was more meaningful to compare the groups because all surgical procedures were performed by the same surgeon. 
In this study, perioperative or postoperative complications were compared between the two different surgical procedures. Regarding perioperative complications, uncontrolled bleeding at the surgical site and dura injuries can be expected when preparing the bed for the implant. Infection and hypertrophic tissue healing at the incision site are the most common postoperative complications. ${ }^{17}$ No perioperative complications in the present study were observed. With regard to postoperative complications, tissue necrosis was observed for the punch technique in the early postoperative period, which was attributed to the extended duration of pressure dressing due to improper patient follow-up. Similarly, tissue granulation in the late postoperative period for the linear incision technique was related to inadequate hygiene. Both complications were improved with medical treatment.

Goldman et al. reported no postoperative complications among 15 patients who were implanted with BAHS using the punch technique. ${ }^{8}$ The complication rate in patients undergoing linear incision varies depending on whether or not subcutaneous tissue is removed. Skin problems are more frequently observed when subcutaneous tissue is removed. Van der Stee et al. divided their patient groups into those who underwent the linear incision technique, with and without subcutaneous tissue excision, respectively. ${ }^{18}$ of the 83 patients who had subcutaneous tissue removed, 28 were reported to have dehiscence at the incision site, and two required surgical intervention. In contrast, none of the 58 patients without subcutaneous tissue removal encountered any problems at the incision site. ${ }^{18}$ Ozmen et al. reported that of the four patients who underwent BAHS using the dermatome technique, only one case developed granuloma at the incision site, and this regressed with local treatment and regular dressing. ${ }^{19}$ These studies show that the possibility of complications decreases with the shift in surgical applications to more minimally invasive methods.

Since the punch technique we used is a newer method, the follow-up period of the patients who underwent linear incision technique was longer. A limitation of our study is that the follow-up times are not equal. Comparing the complications, the early complication in the punch group was not seen in linear incision technique, but granulation tissue was observed in the linear incision technique group in the late postoperative period, which we did not see in the punch technique group. The mean follow-up time was 114 months for the linear incision technique group and 53 months for the punch technique group. The fact that we did not see significantly different complications between the two groups suggests that both techniques are safe.

The punch technique is a minimally invasive surgical procedure used in patients undergoing BAHS implantation. The duration of surgery was significantly decreased in patients who underwent the punch technique, and, significantly, this method did not increase the rate of surgical complications. The punch technique is a preferable surgical method because of the shorter duration of surgery as well as for cosmetic reasons.

\section{Discussion of Audiological Results}

In the current study, no differences in pre and postoperative hearing thresholds with supra-aural headphones in the two surgical groups were expected. Although hearing thresholds with BAHS were close to normal, speech recognition thresholds remained inferior to normal hearing. Between the two surgical methods, postoperatively, there were no significant differences in either hearing thresholds or in word recognition scores (-Tables $\mathbf{2}$ and $\mathbf{3}$ ).

Pekkarinen et al. compared patients who had sensorineural hearing loss (SNHL) or CHL to people with normal hearing, and they reported a greater increase in noise ratio for SNHL than for $\mathrm{CHL}^{20}$ They noted that $\mathrm{CHL}$ was closer to normal hearing, although it still had lower scores. In a study conducted by Bayat et al., the gaps-in-noise test performance of $\mathrm{CHL}$ cases was significantly lower than normal hearing. ${ }^{21}$ In the current study, hearing loss had a negative effect on speech-in-noise scores when compared with normal hearing (-Table 4). The significant difference between word recognition scores for normal hearing and BAHS patients showed that decreasing the signal level and increasing the competing noise amount reduced BAHS patients' perceptual ability (-Table 4). These findings agree with the literature.

Synchronization of the hearing system as a result of improved temporal synchrony and spectral resolution helps to improve speech perception. It is well known that temporal auditory processing is degraded in subjects with SNHL, and it is important to present spectrally rich information to the auditory nerve for good speech perception. Due to the lack of stimulus in these temporal cues, deterioration occurs far more quickly, and recognition scores are decreased for people with SNHL; however, with early intervention in people with $\mathrm{CHL}$, their quality of life can be improved by preserving recognition scores since there are no problems in the inner ear or cochlear nerve. ${ }^{22,23}$ Gurses et al. studied word discrimination scores at $0 \mathrm{~dB}$ and $+10 \mathrm{~dB}$ SNR levels in patients with a unilateral BAHS implant. They found that speech discrimination scores of BAHS users were significantly lower than for those with normal hearing. ${ }^{24}$ In the current study, it was found that BAHS patients had lower SNR scores compared with people with normal hearing ( - Table 4 ).

When patient satisfaction with the BAHS implant was evaluated, high device satisfaction was observed in both groups, with no significant differences between them (-Table 5). Although BAHS satisfaction was high in both groups, total scores and subscale scores were higher in the linear incision technique. In a study of 60 patients by Arunachalam et al., ${ }^{25}$ GBI results were given as 34.0 and 21.0 in the social subscale, and 10.0 in the physical subscale. In a study of 49 patients performed by McLarnon, ${ }^{26}$ the total GBI score was found to be 33.3 . Lekue ${ }^{27}$ stated this value as 40.7 in total and 55.2, 14.0, and 9.3 in general health, social and physical subscales, respectively. Despite high satisfaction rates, BAHS is not accepted by some patients. Cosmetic concerns and social problems are among the main reasons for choosing to ignore hearing loss. Zawawi et al., in their study, detected this most frequently in patients with unilateral sensorineural hearing loss and they found $11 \%$ of patients in total who refused treatment. In this study, patients were satisfied with both surgical techniques and accepted the treatment. However, several patients stated that their comprehension problems continued in noisy 
environments. The possible factors that negatively affect the listening performance in BAHS patients have been described previously. These are basically a result of the placement of the device away from the pinna and with unilateral use. ${ }^{28}$

\section{Conclusion}

When the parameters, such as BAHS satisfaction, hearing thresholds, and speech recognition scores, were evaluated between the two groups, no significant audiological differences were found. In addition, the punch technique demonstrated an advantage in terms of shorter surgery duration and no increased risk of surgical complications. Therefore, the punch technique is the preferable surgical method. Periodic audiological control of these patients is also important to monitor the progression of speech recognition scores and to provide important data for future studies.

\section{Conflict of Interests}

The authors have no conflict of interests to delcare.

\section{References}

1 Tjellström A, Lindström J, Hallén O, Albrektsson T, Brånemark PI. Osseointegrated titanium implants in the temporal bone. A clinical study on bone-anchored hearing aids. Am J Otol 1981;2(04):304-310

2 de Wolf MJ, Hendrix S, Cremers CW, Snik AF. Better performance with bone-anchored hearing aid than acoustic devices in patients with severe air-bone gap. Laryngoscope 2011;121(03):613-616. Doi: 10.1002/lary.21167

3 Kompis M, Wimmer W, Caversaccio M. Long term benefit of bone anchored hearing systems in single sided deafness. Acta Otolaryngol 2017;137(04):398-402. Doi: 10.1080/00016489.2016.1261410

4 Tjellström A, Granström G. One-stage procedure to establish osseointegration: a zero to five years follow-up report. J Laryngol Otol 1995;109(07):593-598. Doi: 10.1017/s0022215100130816

5 Tjellström A. Osseointegrated implants for replacement of absent or defective ears. Clin Plast Surg 1990;17(02):355-366

6 Tjellström A, Granström G. How we do it: Frequency of skin necrosis after BAHA surgery. Clin Otolaryngol 2006;31(03): 216-220. Doi: 10.1111/j.1749-4486.2006.01152.x

7 Hultcrantz M. Outcome of the bone-anchored hearing aid procedure without skin thinning: a prospective clinical trial. Otol Neurotol 2011;32(07):1134-1139. Doi: 10.1097/MAO.0b013e31822a1c47

8 Goldman RA, Georgolios A, Shaia WT. The punch method for bone-anchored hearing aid placement. Otolaryngol Head Neck Surg 2013;148(05):878-880. Doi: 10.1177/0194599813476666

9 Bonilla A, Magri C, Juan E. Findings from the experience with the punch technique for auditory osseointegrated implants: A retrospective single center comparative study. Acta Otorrinolaringol Esp (Engl Ed) 2017;68(06):309-316. Doi: 10.1016/j.otorri.2017.01.005

10 DI Giustino F, Vannucchi P, Pecci R, Mengucci A, Santimone R, Giannoni B. Bone-anchored hearing implant surgery: our experience with linear incision and punch techniques. Acta Otorhinolaryngol Ital 2018;38(03):257-263. Doi: 10.14639/0392-100X-1694

11 Dumon T, Medina M, Sperling NM. Punch and Drill: Implantation of Bone Anchored Hearing Device Through a Minimal Skin Punch Incision Versus Implantation With Dermatome and Soft Tissue
Reduction. Ann Otol Rhinol Laryngol 2016;125(03):199-206. Doi: $10.1177 / 0003489415606447$

12 Durankaya SM, Şerbetcioglu M, Dalkılıç G, Gurkan S, Kırkım G. Development of a Turkish monosyllabic word recognition test for adults. J Int Adv Otol 2014;10:172-180

13 Kara K, Tarkan Ö Evaluation of Hearing Results and Quality of Life in Patients with Implanted Bone-Anchored Hearing Devices Master Thesis, Cukurova University Faculty of Medicine, Adana. 2014

14 Dillon H. Hearing Aids. Sydney,. Australia: Boomerang Press; 2001

15 Caruso A, Giannuzzi AL, Sozzi V, Sanna M. Bone anchored hearing implants without skin thinning: the Gruppo Otologico surgical and audiological experience. Eur Arch Otorhinolaryngol 2017; 274(02):695-700. Doi: 10.1007/s00405-016-4305-x

16 Alshehri H, Alsanosi A, Majdalawieh O. Modified Baha Punch Technique: Least Invasive, Shortest Time and No Suturing. Indian J Otolaryngol Head Neck Surg 2016;68(01):80-86. Doi: 10.1007/ s12070-015-0929-1 6

17 Holgers KM, Tjellström A, Bjursten LM, Erlandsson BE. Soft tissue reactions around percutaneous implants: a clinical study of soft tissue conditions around skin-penetrating titanium implants for bone-anchored hearing aids. Am J Otol 1988;9(01):56-59

18 van der Stee EHH, Strijbos RM, Bom SJH, Hol MKS. Percutaneous bone-anchored hearing implant surgery: linear incision technique with tissue preservation versus linear incision technique with tissue reduction. Eur Arch Otorhinolaryngol 2018;275(07): 1737-1747. Doi: 10.1007/s00405-018-5005-5

19 Ozmen ÖA, Basut O, Early Experiences with Bone Anchored Hearing Aid in Uludag University. Early Experiences with Bone Anchored Hearing Aid in Uludag University. Journal of Uludağ University Medical Faculty 2010;36:111-115

20 Pekkarinen E, Salmivalli A, Suonpää J. Effect of noise on word discrimination by subjects with impaired hearing, compared with those with normal hearing. Scand Audiol 1990;19(01):31-36. Doi: 10.3109/01050399009070749

21 Bayat A, Farhadi M, Emamdjomeh H, Saki N, Mirmomeni G, Rahim F. Effect of conductive hearing loss on central auditory function. Rev Bras Otorrinolaringol (Engl Ed) 2017;83(02):137-141. Doi: 10.1016/j.bjorl.2016.02.010

22 Moore B. An Introduction to the Psychology of Hearing. London: GB Academic Press; 2003

23 Moller AR. Hearing: Anatomy, Physiology, and Disorders of the Auditory System. San Diego: USA Plural Publishing Inc; 2013

24 Gürses E, Türkyılmaz MD, Sennaroğlu G. Evaluation of auditory temporal processing in patients fitted with bone-anchored hearing aids. Eur Arch Otorhinolaryngol 2020;277(02):351-359. Doi: 10.1007/s00405-019-05701-4

25 Arunachalam PS, Kilby D, Meikle D, Davison T, Johnson IJ. Boneanchored hearing aid quality of life assessed by Glasgow Benefit Inventory. Laryngoscope 2001;111(07):1260-1263. Doi: 10.1097/00005537-200107000-00022

26 McLarnon CM, Davison T, Johnson IJ. Bone-anchored hearing aid: comparison of benefit by patient subgroups. Laryngoscope 2004; 114(05):942-944

27 Lekue A, Lassaletta L, Sánchez-Camón I, Pérez-Mora R, Gavilán J. Calidad de vida de pacientes implantados con el dispositivo BAHA según su indicación [Quality of life in patients implanted with the BAHA device depending on the aetiology]. Acta Otorrinolaringol Esp. 2013;64(01):17-21. Doi: 10.1016/j.otorri.2012.06.006

28 Oeding K, Valente M. The effectiveness of the directional microphone in the Oticon Medical Ponto Pro in participants with unilateral sensorineural hearing loss. J Am Acad Audiol 2013;24 (08):701-713. Doi: $10.3766 /$ jaaa.24.8.7 